\title{
Effects of plant density on photosynthetic characteristics and yield of maize under irrigation condition
}

\author{
Mahama Salifu - Lajos Fülöp Dóka \\ Institute of Crop Sciences, Faculty of Crop Production and Horticulture Science, University of Debrecen, H-4032 Debrecen, Böszörményi \\ Str. 138 \\ Salifumahama@agr.unideb.hu
}

SUMMARY

\begin{abstract}
Maize plant response to plant density is an essential agrotechnical factor used for determining grain yield. Three plant densities (60,000 ha-1, 72,500 $\mathrm{ha}^{-1}$, and 85,000 $\mathrm{ha}^{-1}$ ) were used in this study to ascertain the effect of photosynthetic parameters and grain yield. Results show a significant difference in the photosynthetic parameters (SPAD, NDVI, LAI) and plant height for plant density of 85,000 ha-1. Grain yield and stem diameter were not significantly affected between the different plant densities.
\end{abstract}

Keywords: Maize, plant density, photosynthesis, grain yield

\section{INTRODUCTION}

Maize (Zea mays L) is one of the most important cereal crops in the world. It is a major grain cereal crop that has many uses for human beings and for industrial uses. Maize is the second largest arable crop in the world regarding its production area $(177,379,507$ ha plus $1,125,916$ ha green maize). Its global production was $872,066,770$ tons plus $9,764,006$ tons for green maize (FAO, 2012). Maize plant density and temperature sources improve plants' tolerance to drought stress and are a measure to increasing plants' potential yield (Dai 2000). Maize plant density is an essential crop factor in production that can greatly affect plant growth and grain yield. The task of maize crop producers is to find an optimum plant density where the negative effect of plant competition will significantly decrease, thus resulting in optimum grain yield. Studies of (Murányi and Pepó, 2013, Dawadi and Sah, 2012) concluded that plant height increases as plants density increases. The maize plant morphological parameters such as leaf area, plant height and stalk diameters were well expressed as a result of the effects of plant density and the differences between maize hybrids (Berzsenyi and Lap, 2006).

Studies conducted in Iowa in 2002, indicate that an American grain yield recorded $27,754.4 \mathrm{~kg} \mathrm{ha}^{-1}$ under non-irrigated conditions, with a harvest of density of 108,900 plants per hectare (Sun 2003). Increased in plant density results in shading which can cause depression in photosynthesis and competition for water and plant available nutrient (Marchiori et al., 2014) Photosynthetic parameters are mostly explored mechanisms in plant physiology which is advanced with which plants photosynthetic efficiency can be affected in various forms (Horvath et al., 1998; Perreault et al., 2011).

Chlorophyll fluorescence is used for assessment of plant reaction to various types of plant stress conditions (Apprenroth et al., 2001). Photosynthetic efficiency is an indicator of plant vitality which is a sensitive parameter of test which takes into consideration all the main photochemical processes. Photosynthesis parameter analysis is suitable for researchers in the descriptions of cultivars in normal and in stress conditions of plants and their reaction to stress factors in production. Photosynthesis is the one of the basic factors of yield formation and its importance to plant densities cannot be over-emphasized in determining its role in grain yield.

Water supply to crops plays an important role in crop production and has become necessary due to the recent climatic changes all over the world. Inadequate supply of water to crops as a result of climatic changes leads to the use of irrigation in most farming production centres worldwide. Water plays a major role in the utilization of chemical fertilizers by plants, especially nitrogen, due to changing precipitation conditions. As regards irrigation and fertilizer research results, Nagy (1995, 1997, 1999) has indicated that irrigation improves the efficiency of fertilization and there is a strong correlation between water supply and fertilizer utilization by plants. The effect of fertilization increases with optimal water supply and decreases when harmful water excess is reached (Nagy, 1994, 2000, 2001). The purpose of this current study is to access the impact of plant density on the photosynthetic parameters on maize yield under irrigated conditions.

\section{MATERIALS AND METHODS}

A field experiment was set up at the experimental farm of the University of Debrecen at Látókép, about $15 \mathrm{~km}$ away from the city centre with (Latitude $47^{\circ} 33^{\prime} \mathrm{N}$ and Longitude $21^{\circ} 27^{\prime} \mathrm{E}$ ). The area of Látókép Crop Production Experiment Site lies along road no. 33 and has an independent water extraction facility which provides water necessary for irrigation from the water reservoir. The soil for the experimental site calcareous chernozem formed on the Hajdúság loess ridge. The prevailing climate and weather conditions are continental and often extreme. The 30-year average value of precipitation is $565.3 \mathrm{~mm}$, (Table 1), while the precipitation during the periof between planting and harvesting was $290.4 \mathrm{~mm}$. (Figure 1) 
30-year average of precipitation and temperature

\begin{tabular}{lcc}
\hline Month & Precipitation & Temperature \\
\hline January & 37.0 & -2.6 \\
Febuary & 30.2 & 0.2 \\
March & 33.5 & 5.0 \\
April & 42.4 & 10.7 \\
May & 58.8 & 15.8 \\
June & 79.5 & 18.7 \\
July & 65.7 & 20.3 \\
August & 60.7 & 19.6 \\
September & 38.0 & 15.8 \\
October & 30.8 & 10.3 \\
November & 45.2 & 4.5 \\
December & 43.5 & -0.2 \\
\hline Average & 565.3 & 9.84 \\
\hline
\end{tabular}

Figure 1: Precipitation (mm) and temperature $\left({ }^{\circ} \mathrm{C}\right)$ during the growing season

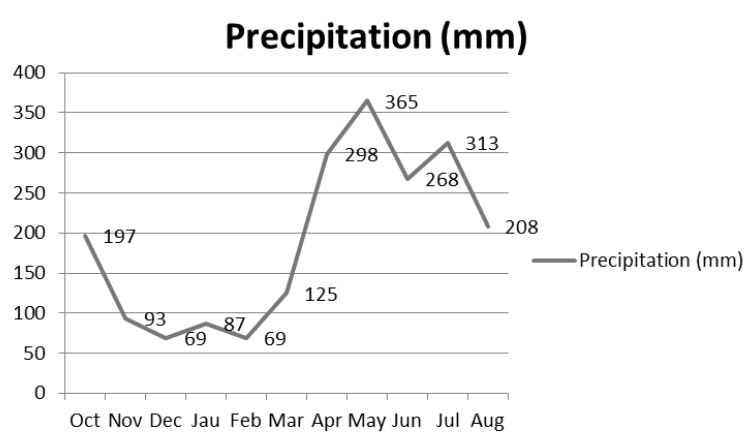

Source: Debrecen-Látókép 2018

The experiment was established on a plot where the preceding crop and fertilization were set in four replications in a split-plot design on a fully irrigated plot. The maize seeds were planted on $10^{\text {th }}$ of May and harvested on the $10^{\text {th }}$ of September. Three planting densities were used, thus 60,000 per hectare, 72,500 per hectare and 85,000 per hectare.

The irrigation dates and amount of water in used in millimeters were as follows;

$24^{\text {th }}$ June, 2018: $50 \mathrm{~mm}$

$9^{\text {th }}$ July, 2018: 50mm

$30^{\text {th }}$ July, 2018: $25 \mathrm{~mm}$

$6^{\text {th }}$ August, 2018: $25 \mathrm{~mm}$

Photosynthetic parameters (SPAD, LAI, NDVI) were measured at four different times at different growth stages of the maize plant (vegetative stage 6 vegetative stage 18). The measuring dates were as follows;

$25^{\text {th }}$ May, 2018

$12^{\text {th }}$ June, 2018

$3^{\text {rd }}$ July, 2018 and

$7^{\text {th }}$ October, 2018.

The LAI values were recorded using SS1- Sun Scan Canopy Analysis System (Delta-T Device, UK). The chlorophyll content was measured using SPAD-502 Plus (Konica Minolta, Japan). NDVI values were taken

\section{Temperature}

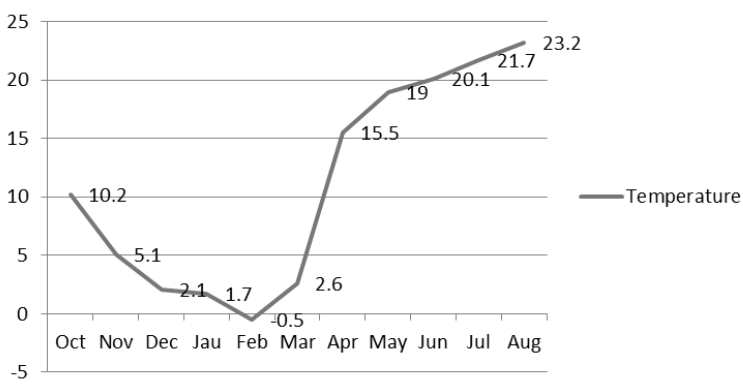

with GreenSeeker Handheld Crop Sensor. Plant height and stem diameter were manually recorded just before harvest using a long ruler and a vernier caliper respectfully by randomly selecting 10 plants from each plot. The statistical analysis was competed using SPSS version 19 and Microsoft Excel.

\section{RESULTS AND DISCUSSION}

The Soil Plant Analysis Development (SPAD) which measures the chlorophyll content of plant leaves in the field was significantly affected by plant density. Low SPAD readings were obtained in the case of a plant density of $60,000 \mathrm{ha}^{-1}$, compared to the 72,500 $\mathrm{ha}^{-1}$ and 85,000 ha- $\mathrm{ha}^{-1}$ plant densities. The findings in this study coincide with those of (Antonietta et al. 2014), i.e., higher plant density accelerates the rate of leaf senescence. Higher plant density of maize increases the vegetative growth resulting in a higher number of leaves and more intense leaf extension per plant which leads to interception of lights rays on the plants to facilitate photosynthetic activities. Amanullah et al. (2008) observed that higher density increases plant height as well as light interception which ultimately leads to higher grain yields as compared to low plant densities. The findings of (Toler et al., 1999) show $15 \%$ 
light interception and plants' biomass yield at high density in comparison with low density.

Leaf is an essential plant organ which is associated with photosynthesis and evapotranspiration and its measurement is required in plant physiology and agronomical studies involving plant growth (Guo and Sun, 2001). Leaf Area Index (LAI) was recorded with lower values for low plant density of $60,000 \mathrm{ha}^{-1}$. There was a highly significant difference between the three plant densities as shown in Table 2 below. Maize leaf area affects interception and the utilization of solar radiation of crop canopy, thereby activating the photosynthetic activities of plants which will result in the maize plant dry matter accumulation and yield increase. (Boote et al., 1996) states that leaf area is an important factor in the estimation of canopy photosynthesis in crop growth simulation models that compute dry matter accumulation. The result of this study is consistent with (Dwyer et al., 1991) that shows that high plant population may increase maize leaf area to more than 5. Consequently, choosing a higher plant density tolerant maize variety is a critical step towards achieving high yielding breakthrough in maize producing farms.

Normalized Difference Vegetative Index (NDVI) is a measure of the absorption of solar radiation in the photosynthetically active radiation spectral of live green plants which is used as a source of energy in the process of photosynthesis. A measure of this index in this study shows a significant difference between high and low plant densities. This could be understood because all photosynthetic characteristics show a positive relationship with high plant density. Studies have shown that NDVI is used to predict nitrogen requirements of maize plants and has proved to be very effective in determining field crop leaf nitrogen variability (Sripada et al., 2005; Raun et al., 2004).

Effects of plant density on photosynthetic parameters on growth and yield of maize

\begin{tabular}{ccccccc}
\hline $\begin{array}{c}\text { Plant } \\
\text { density }\end{array}$ & SPAD & NDVI & LAI & Height (M) & $\begin{array}{c}\text { Stem } \\
\text { diameter (M) }\end{array}$ & $\begin{array}{c}\text { Yield } \\
\mathrm{kg} \mathrm{ha}^{-1}\end{array}$ \\
\hline $60,000 \mathrm{ha}^{-1}$ & $53.42 \mathrm{a}$ & $0.72 \mathrm{a}$ & $0.67 \mathrm{a}$ & $247.95 \mathrm{a}$ & $2.19 \mathrm{a}$ & $11404.31 \mathrm{a}$ \\
$72,500 \mathrm{ha}^{-1}$ & $58.27 \mathrm{~b}$ & $0.74 \mathrm{a}$ & $2.26 \mathrm{~b}$ & $253.35 \mathrm{a}$ & $2.28 \mathrm{a}$ & $12099.32 \mathrm{a}$ \\
$85,000 \mathrm{ha}^{-1}$ & $64.91 \mathrm{c}$ & $0.77 \mathrm{~b}$ & $3.59 \mathrm{c}$ & $268.35 \mathrm{~b}$ & $2.30 \mathrm{a}$ & $12284.39 \mathrm{a}$ \\
\hline SIG. & 0.000 & 0.000 & 0.000 & 0.000 & 0.234 & 0.280 \\
\hline
\end{tabular}

Data marked with the same letter in the same Columns is not significantly different at the significance level of 0.05 .

Maize plant height is one of the important components of plants in determining plant growth. The effect of plant density on maize height was significantly noticed in this study as shown in Table 2 above. Plants become taller as plant densities increased from 60,000 $\mathrm{ha}^{-1}$ to $85,000 \mathrm{ha}^{-1}$. The lowest plant height recorded was the plant population of $60,000 \mathrm{ha}^{-1}$. There was no significant difference between the plant densities of 60,000 and 72,500 in this study as shown in Table 2 above. The results of the obtained research could be understood in that the morphological characteristics of the maize plant in this study is similar to LAI. From Table 2 above, there was not significant difference in stem diameter although plant density of $85,000 \mathrm{ha}^{-1}$ shows a little higher value of $2.30 \mathrm{~mm}$. This phenomenon could be attributed to overcrowding or insufficient plant nutrients in the field. Increasing plant density would require more nitrogen and water supply. The results of this research are in conformity with other researchers, such as (Dawadi and Sah, 2012; Gozubenli H. et al., 2004). Measurements from the above table indicate that there is no significant difference in grain yield in this experiment, even though plant density of $85,000 \mathrm{ha}^{-1}$ recorded high mean values against the 60,000 and 72,500 plant density values for grain yield.

Maize crop grain yield depends on a lot of agrotechnical factors such as nutrient supply, planting distance and environmental factors such as high temperature, water availability for plant uptake etc. Plant density has a decisive influence on grain yield of maize. According to (Tokatlidis and Koutrubas, 2004), the optimum plant density resulting in maximum yield has increased due to the great plant density tolerance of the new maize hybrids. The study results of (Mohseni et al., 2013) shows an increase in grain yield of plants from plant density of 60,000 plants ha- $\left(9.09 \mathrm{t} \mathrm{ha}^{-1}\right)$ to 80,000 plants ha ${ }^{-1}\left(11.14 \mathrm{t} \mathrm{ha}^{-1}\right)$. (Roekel and Coulter, 2011) indicated that there is a close relationship between maize yield and plant density. The results of the current study coincide with the above cited researchers.

\section{CONCLUSION}

Maize plant responds to different plant densities under different environmental and under different agrotechnical conditions differently. From our results, it could be observed that plant density has a significant influence on the photosynthetic characteristics of maize plants (SPAD, LAI, NDVI), but has a marginal effect on the crop stem diameter and grain yield. The cause of the increase in plant height could be attributed to competition for sunlight and the marginal effect on grain yield could be a result of overcrowding stress which reduces grain yield per plant when plant density is not enough to compensate for the reductions in grain yield. There is a need to repeat this study since one year of experimental data is not enough to make a general conclusion and, consequently, it could only be assigned as an initial finding of results and bases for other researchers to work on this area of research. 


\section{REFERENCES}

Amanullah, R.-Rahman, H.-Shah, Z. (2008): Effects of plant density and $\mathrm{N}$ on growth dynamics and light interception in maize. Arch. Agron. Soil Sci., 54: 401-411.

Antonietta, M.-Fanello, D. D.-Acciaresi, H. A.-Guiamet, J. J. (2014): Senescence and yield responses to plant density in stay green and earlier-senescing maize hybrids from Argentina. Field Crop Res 155:111-119

Berzsenyi. Z.-Lap, D. Q. (2006): "Use of Richards function to analyses the effect of plant density on the growth of vegetative and reproductive organs in maize (Zea mays L.) Hybrids from different maturity groups"' in crop production. Vol. 55. (3-4.) pp.255-275.

Boote, K. J.-Jones, J. W.-Pickering, N. B. (1996): Potential uses and limitations of crop models. Agron. J., 88: 704-716.

Dawadi, D. R.-Sah, S. K. (2012): ' Growth and yield of hybrid maize (Zea mays L.) in relation to planting density and nitrogen levels during winter season in Nepal'”. Tropical Agricultural Research. Vol.23.(3) pp.218-227

Dawadi. D. R.-Sah, S. K. (2012): "Growth and yield of hybrid maize (Zea mays L.) in relation to planting density and nitrogen levels during winter season in Nepal" in Tropical Agricultural Research. Vol.23. (3) pp.218-227

Dwyer, L. M.-Tollenaar, M.-Stewart, D. W. (1991): Changes in plant density dependence of leaf photosynthesis of maize (Zea mays L.) hybrids. Can.J. Plant Sci., 71, PP.1-11

Gozubenli, H.-Klinic, M.-Sener, O.-Konuskan. (2004): Effects of single and twin row planting on yield and yield components in maize. Asian Journal of Plant Sciences. Vol. 3. (2) pp.203-206.

Guo, D. P.-Sun, Y. Z. (2001): Estimation of leaf area of stem lettuce (Lactuca sativa var angustana) from linear measurements. Indian Journal of Agricultural Sciences, v. 71, n. 7, p. 483-486

http://www.fao.org/3/i3028e/i3028e00.htm

Mohseni, M.-Sadarov, M.-Haddadi, H. (2013): Study of tillage, plant pattern and plant densities on kernel yield and its component of maize in Iran. International Journal of Agriculture and Crop Sciences. 5. (15) 1682- 1686.

Murány, E.-Pepó, P. (2013): The effects of plant density and row spacing on the height of maize hybrids of different vegetation time and genotype. International Journal of Agricultural and Biosystems Engineering vol., $7 \quad$ (11). Waset.org/publication/1752.
Nagy, J. (1994): The effect of fertilization and irrigation on the yield of maize (Zea mays L.) hybrids with varions genotypes. Unipress, Padova, 421-440.

Nagy, J. (1995): Evaluating the effect of fertilization on the yield of maize (Zea mays L.) in different years. Növénytermelés, 44. 56. 493-506.

Nagy, J. (1997): The effect of fertilization on the yield of maize (Zea mays L.) in unirrigated and irrigated cultivation. Agrokémia és Talajtan, 46. 1-4. 275-288.

Nagy, J. (1999): Evaluation of interaction between irrigation and soil cultivation maize production. Acta Agronomica, 47. 2. 181-190.

Nagy, J. (2000): A talajművelés és a mütrágyázás hatása a kukorica (Zea mays L.) termésére aszályos és kedvező évjáratokban. In: Nagy, J.-Pepó, P. (szerk.) Növény. és talajtudomány a mezőgazdaságban. Vider Plussz, Debrecen, 97-119.

Nagy, J. (2001): The effect precipitation on the yield of maize (Zea mays L.). In: Nagy, J. et al. (ed.) Current soil and environmental science in agriculture. Debrecen, 177-190.

Raun, W. R.- Solie, J. B.- Johnson, G. V.-Stone, M. L.-Martin, K. L.-Freeman, K. W.-Mullen, R. W.-Zhang, H.-Schepers, J. S.Johnson, G. V. (2004): Optical sensor-based alogorithm for crop nitrogen fertilization. Communications in Soil Science and Plant Analysis 36:2759-2781.

Roekel, J. R.-Coulter, A. J. (2011): Agronomic responses of corn top planting date and plant density. Agronomy Journal. 103. (5.) 1414-1422.

Sripada, R. P.- Heiniger, R. W.-White, J. G.- Weisz, R. (2005): Aerial color infrared photography for determining late-season nitrogen requirements in corn. Agronomy Journal 97:1443-1451.

Tokatlidis, S. I.-Koutroubas, D. S. (2004): A review of maize hybrids' dependence on high plant populations and its implications for crop yield stability. Field Crops Research. 88:103-114.

Toler, J. E.-Murdock, E. C.-Stapleton G. S-Wallace, S. U. (1999): Corn leaf orientation effects on light interception, intra-specific competition and grain yields. J. Prod. Agric., 12: 396-399. 